\title{
Augmentation and reduction mammaplasty: demographic and obstetric differences in women attending a National Health Service clinic
}

\author{
Sandra Birtchnell and J. Hubert Lacey \\ Academic Department of Psychiatry, St. George's Hospital Medical School, London SW17 ORE, UK.
}

\begin{abstract}
Summary: Women presenting for breast augmentation and breast reduction to a National Health Service plastic surgery/psychiatry liaison clinic appear to differ beyond the anatomical. Those requesting breast reduction tend to be younger, unmarried and not to have been pregnant and may be uncomfortable with adult sexuality. Those requesting breast augmentation are presenting for surgery in their mid-thirties although many have always had small breasts. This is at a time of fading attractiveness, marital difficulties and a sense of failure as a woman. We report a strikingly poor obstetric history in this group.
\end{abstract}

\section{Introduction}

A woman's breast symbolize to her, and to others that observe her, her femininity, womanliness, sensuality and ability to nurture. ${ }^{1,2}$ Across the centuries and in many different cultures breasts figure large on symbolic representations such as statues of fertility goddesses, this meaning enduring through transient periods in history when fashion dictates that the breasts are de-emphasized. There is a tendency for breast size to be judged with reference to an ideal, where 'normal' is equated with large, rather than reference to the statistical normal distribution of breast size in a female population. ${ }^{3}$ However one can have 'too much of a good thing', ${ }^{2}$ and very large breasts may constitute both a physical and psychological handicap.

Not all women with abnormally small or large breasts request corrective plastic surgery. This study delineates some of the characteristics of those that do.

\section{Method}

The data presented were collected as part of the psychiatric assessment of women requesting National Health Service augmentation and reduction mammaplasty referred by the surgeon to the plastic surgery/psychiatry liaison clinic. All those patients presenting over a 4 year period have been included.

Correspondence: J.H. Lacey M.D., N.Phil., F.R.C.Psych. Accepted: 6 January 1988
Augmentation mammaplasty is viewed as a $\frac{c}{\mathscr{C}}$ purely cosmetic operation, and a second opinion supporting the operation on psychological ground is necessary if the patient is to receive Nationa Health Service surgery. All patients requesting the operation, referred by their general practitioner to the surgeon were therefore also seen in the liaison clinic. This does not apply to breast reconstruction after mastectomy, and such patients are not included in this study.

Reduction mammaplasty can, on occasion, be viewed as a physical necessity rather than purely cosmetic. In the presence of clinical complications of macromastia such as vertebral or respiratory problems, a psychiatric opinion to support surgery on psychological grounds would not need to be sought, and such patients were not referred by the surgeon to the liaison clinic. They are therefore not included in this study. All patients requesting this operation referred to the liaison clinic are included in this study, thus representing approximately half the referrals made to the surgeon, the others being placed on the waiting list for surgery on physical grounds.

\section{Results}

Ten women requesting breast augmentation and $\stackrel{0}{\odot}$ nine women requesting breast reduction were seen. $\stackrel{\oplus}{+}$ Their age, marital status and obstetric/gynaecological history are shown in Table I.

In the breast augmentation group, most were

(C) The Fellowship of Postgraduate Medicine, 1988 
Table I Characteristics of women requesting augmentation and reduction mammaplasty

\begin{tabular}{|c|c|c|c|}
\hline & & $\begin{array}{c}\text { Breast } \\
\text { reduction }\end{array}$ & $\begin{array}{c}\text { Breast } \\
\text { augmentation }\end{array}$ \\
\hline Number & & 9 & 10 \\
\hline Age & & $\begin{array}{l}23.1 \text { years } \\
\text { s.d. } \pm 5.69\end{array}$ & $\begin{array}{l}33.4 \text { years } \\
\text { s.d. } \pm 4.45\end{array}$ \\
\hline Marital status & $\begin{array}{l}\text { Married } \\
\text { Single } \\
\text { Divorced/separated }\end{array}$ & $\begin{array}{c}1(11.1 \%) \\
7 \\
1\end{array}$ & $\begin{array}{c}7(70 \%) \\
1 \\
2\end{array}$ \\
\hline Obstetric history & $\begin{array}{l}\text { Total no. pregnancies } \\
\text { Living children } \\
\text { Termination } \\
\text { Miscarriage } \\
\text { Still birth }\end{array}$ & $\begin{array}{l}8 \\
1 \\
7 \\
0 \\
0\end{array}$ & $\begin{array}{c}38 \\
26 \\
4 \\
3 \\
1^{*} \\
\text { (33.3 per } 1000 \\
\text { live births) }\end{array}$ \\
\hline . & $\begin{array}{l}\text { Death in infancy } \\
\text { (under } 1 \text { year) }\end{array}$ & $\begin{array}{l}0 \\
0\end{array}$ & $\begin{array}{c}3^{*} \\
(100 \text { per } 1000 \\
\text { live births) } \\
(+1 \text { death at } 18 \text { months }) \\
2 \\
1\end{array}$ \\
\hline
\end{tabular}

*Comparable figures for South West Thames Region: stillbirth 5.6 per 1000 live births; death in infancy 10.7 per 1000 live births (District Profile: Demography, Mortality, Morbidity. Wandsworth Health Authority, 1983).

married, but two of the seven marriages were second marriages and no marriage was not under strain. Four women reported that their husbands had been unfaithful. The one unmarried patient in this group had ended a 5 year relationship 6 months prior to consultation. Details of the obstetric history are shown in Table II.

The breast reduction group are younger and predominantly single. The sample included a lesbian, a woman who had been raped by her uncle and a woman who had been sexually molested, her breasts being touched. Attempts to lose weight were commonly reported and changes of weight of 3 and 4 stone were declared by two patients; three patients admitted binge-eating. The living child was born to the one married woman in this group, who was pregnant at the time of marriage. Six of the seven terminations were reported by the one, twice divorced, patient.

\section{Discussion}

Although the women requesting augmentation had always been flat chested they did not present for surgery until their mid-thirties. Their psychiatric assessment indicated that this was a time of renewed threat to their feminine identity with fading attractiveness, marital difficulties, and, most importantly, a sense of failure as a mother. Addi- tionally, there was a vicious circle of sexual inhibition occasioned by self-consciousness of their small breasts contributing further strain to an already strained marriage. The striking obstetric history given by these patients, with a death in infancy rate some 10 fold greater than expected, has not been previously reported.

Descriptions of those seeking augmentation mammaplasty are remarkably consistent ${ }^{3-9}$ and confirmed again in this study. The common theme is that doubt concerning femininity motivates the

Table II Obstetric history of women requesting augmentation mammaplasty

\begin{tabular}{|c|c|c|}
\hline Case & & History \\
\hline 1 & Para $4+0$ & \\
\hline 2 & Para $4+1$ & $\begin{array}{l}\text { Miscarriage shortly befure consul- } \\
\text { tation. Husband wanted pregnancy } \\
\text { terminated }\end{array}$ \\
\hline 3 & Para $5+0$ & Sterilized \\
\hline 4 & Para $0+3$ & Terminations \\
\hline 5 & Para $3+2$ & $\begin{array}{l}\text { (4th) stillbirth (5th) cot death at } 2 \\
\text { months, sterilized }\end{array}$ \\
\hline 6 & Para $2+0$ & Children in custody of ex-husband \\
\hline 7 & Para $1+5$ & $\begin{array}{l}\text { (1st) Epileptic (2nd) cot death (3rd) } \\
\text { termination }(4 \text { th }+5 \text { th) miscarriage } \\
\text { (6th) death at } 18 \text { months (nephrotic } \\
\text { syndrome) }\end{array}$ \\
\hline 8 & Para $1+0$ & Investigated for infertility \\
\hline 9 & Para $4+1$ & (3rd) Infant death at 4 weeks \\
\hline 10 & Para $2+0$ & Son autistic. Hysterectomy \\
\hline
\end{tabular}


request. This study strongly suggests that a poor obstetric history contributes to this doubt.

Doubts have been expressed at the wisdom of colluding with the defensive strategy of boosting a sense of femininity with silicone, but it must be acknowledged that post-operative results are generally extremely satisfactory. $4,6,7,9$

In contrast to those seeking augmentation, who wish to increase, via the symbolism of the breast, their sense of femininity, those seeking reduction mammaplasty appear to be uncomfortable with adult sexuality. Women requesting reduction mammaplasty because of macromastia are not included in this study. The clinical impression is that they are older, and they may well differ in other important respects from the patients seen in the liaison

\section{References}

1. Goin, M.K. Psychological reactions to surgery of the breast. Clin Plast Surg 1982, 9: 347-354.

2. Kaye, B. Micromastia vs macromastia. Medical Aspects of Human Sexuality 1973, August: 96-119

3. Beale, S., Lisper, H. \& Palm, B. A psychological study of patients seeking augmentation mammaplasty. Br J Psychiatry 1980, 136: 133-138.

4. Ohlsen, L., Ponten, B. \& Hambert, G. Augmentation mammaplasty: a surgical and psychiatric evaluation of the results. Ann Plast Surg 1979, 2: 42-52.

5. Edgerton, M.T. \& McClary, A.R. Augmentation mammaplasty. Psychiatric implications and surgical indications. Plast Reconstr Surg 1958, 21: 279-305.

6. Edgerton, M.T., Meyer, E. \& Jacobsen, W.E. Augmentation mammaplasty. Further surgical and psychiatric evaluation. Plast Reconstr Surg 1961, 27: 279-302. clinic, whose request is merely cosmetic. The induction of self consciousness has been described ${ }^{10}$ and these young women may refer to their breasts as 'things' as if to deny they were part of their bodies. One patient in this study requested not so much reduction as bilateral mastectomy. Distinction should be made between those women who have intra-psychic problems concerning their feminine identity and those who are happy and secure as women, but do not wish to be treated as sexual objects. In this group also post-operative outcome is good. ${ }^{11}$

\section{Acknowledgements}

We thank Mr P.J. Whitfield and Mr J.S.P. Wilson for referring these patients.

7. Druss, R.G. Changes in body image following augmentation breast surgery. Int J Psychoanal Psychother 1973, 2: 248-256.

8. Baker, J., Kolin, I. \& Bartlett, E. Psychosexual dynamics of patients undergoing mammary augmentation. Plast Reconstr Surg 1974, 53: 652-659.

9. Sihm, F., Jagd, M. \& Pers, M. Psychological assessment before and after augmentation mammaplasty. Scand J Plast Reconstr Surg 1978, 12: 295-298.

10. Harris, D.L. Self-consciousness of disproportionate breast size: a primary psychological reaction to abnormal appearance. Br J Plast Surg 1983, 36: 191-195.

11. Hollyman, J.A., Lacey, J.H., Whitfield, P.J. \& Wilson, J.S.P. Surgery for the psyche: a longitudinal study of women undergoing reduction mammaplasty. $\mathrm{Br} J$ Plast Surg 1986, 39: 222-224. 